\title{
FEATURES OF PLANNING OF THE STUDIES OF INDOOR AIR LEVELS WITHIN THE ACTION PLAN IMPLEMENTATION
}

\author{
Pavlenko T.O., Aksonov M.V., Fryziuk M.A., Operchuk A.P., Fedorenko O.V. \\ ОСОБЛИВОСТІ ПЛАНУВАННЯ ДОСЛДЖЕНЬ РВНВ РАДОНУ \\ У ПОВІТР БУДИНКІВ У РАМКАХ РЕАЛЗАЦПП ПЛАНУ ДЙ
}

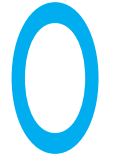

1ПАВЛЕНКО Т.О., 1АКСЬОНОВ М.В., 1ФРИЗЮК М.А., 2ОПЕРЧУК А.П., 1ФЕДОРЕНКО О.В.

1 ДУ «Інститут громадського здоров'я ім. О.М. Марзєєва

НАМН України», м. Київ, Україна

2ДУ «Центр громадського здоров'я МОЗ України», м. Київ, Україна дним 3 першочергових завдань радонового плану дій в умовах обмеженого фінансового забезпечення $€$ окреслення найбільш критичних регіонів щодо ступеня радононебезпечності.

Це завдання $€$ співставним з процедурами оптимізації моніторингу, але має свої особливості. Процедури оптимізації, як правило, розглядаються у контексті аварійного опромінення або практичної діяльності. Обом ситуаціям притаманні специфічні вимоги до обмеження додаткового опромінення населення, а система коригувальних заходів пов'язана або 3 контролем джерела опромінення, або з подоланням наслідків радіаційних аварій [1].

У ситуації існуючого опромінення первинні дослідження рівнів опромінення та оцінка радіаційних ризиків $є$ критеріями для обґрунтування доцільності втручання 3
ОСОБЛИВОСТІ ПЛАНУВАННЯ ДОСЛІДЖЕНЬ РІВНІВ РАДОНУ У ПОВІТРІ БУДИНКІВ У РАМКАХ РЕАЛІЗАЦІЇ ПЛАНУ ДІЙ

1 Павленко Т.О., 1 Аксьонов М.В., 1Фризюк М.А., 2 Оперчук А.П., 1 Федоренко О.В.

1 ДУ «Інститут громадського здоров'я ім. О.М. Марзєєва НАМН України»,

м. Київ, Україна

2ДУ «Центр громадського здоров'я Міністерства охорони здоров'я України", м. Київ, Україна

Мета роботи. Обґрунтування методологічних аспектів дослідження радононебезпеки територій.

Матеріали та методи дослідження.

Вимірювання рівнів радону-222 проводилися в опалювальний сезон методом пасивноі трекової радонометрії з використанням в якості детектора нітрат-целюлозної плівки типу LR-115. Час експонування радонових накопичувачів становив 1-2 місяці. Після процедури хімічного травлення підраховували кількість треків ушкоджень на детекторах методом іскрового підрахунку.

Для визначення ефективності реєстрації (калібрування) трекових детекторів їх експонували у радоновій атмосфері з відомою активністю радону. Радонова атмосфера, запатентована Інститутом громадського здоров'я НАМН України, є еталоном, акредитованим Національним органом стандартизації та акредитації України.

Результати. Виконано вимірювання радо- ну-222 у повітрі понад 30000 житлових будинків. Встановлено, що середнє геометричне значення EPOA радону-222 для одноповерхових будинків сільського типу становило 52 БК $\cdot \mathrm{M}^{-3}\left(\right.$ у термінах ОА - 130 БK $\left.\cdot \mathrm{M}^{-3}\right)$; для квартир, розташованих на першому поверсі багатоповерхівок - 40 (100) БK $\cdot \mathrm{M}^{-3}$, вище першого поверху - 23(58) Бк $\mathrm{M}^{-3} 3 а$ стандартного відхилення - 62 (155) БК $\cdot \mathrm{M}^{-3}$, 48 (120) Бк $\cdot M^{-3}$ та $28(70)$ Б $\cdot M^{-3}$ відповідно. Встановлено, що у середньому по країні рівень нормативу для радону-222 у 100 (250) Бк $\cdot M^{-3}$ перевищується у $19 \%$ випадків, рівень 200 (500) Бк $\cdot M^{-3}$ - у 5, 7\% випадків. Визначено ефективні дози опромінення населення країни. Проаналізовано нерадіаційні фактори, які впливають на ефективність досліджень. Розроблено алгоритм оцінки ступеня радононебезпеки території, який передбачає аналіз структури житлового фонду, визначення найбільш типових інженерно-планувальних рішень будівель, вимірювання радону інтегральним методом, виявлення критичних типів будинків за результатами вимірювання рівнів радону, розрахунок радіаційних ризиків для населення від радону. Визначено основні вимоги до первинного моніторингу радону у контексті реалізації радонового плану дій.

Ключові слова: радон у будинках, ефективна доза, радіаційні ризики, алгоритм дій.

() Павленко Т.О., Аксьонов М.В., Фризюк М.А., Оперчук А.П., Федоренко О.В. 
боку держави і завжди здійснюються на популяційному рівні. У контексті опромінення радоном доцільним критерієм $€$ середньорічна ефективна доза (ЕД). Для оцінки цієї величини вимірюються середньозважені величини активностей радону у будинках та за їхньою величиною проводиться картування радонових ризиків чи потенціалів територій. Такий підхід пов'язаний переважно 3 масштабами досліджень: коли йдеться про радон - це десятки-сотні тисяч вимірювань. Тому перший етап реалізації плану дій - це оптимізація первинного скринінгового дослідження радону у повітрі приміщень житлових та громадських будинків.

Більшість країн на першому етапі досліджень радону запровадили картування його рівнів $[2,5]$. У подальшому ці карти доповнювалися і використовувалися для інформування населення про радонові потенціали територій $[6,7]$.

Другий етап попередніх досліджень радону - це аналіз наявності чинників нерадіаційної природи, які потенційно можуть впливати на реалізацію захисних заходів (демографічна ситуація, соціально-економічні чинники тощо). Суперпозиція цих чинників і буде підґрунтям для визначення та окреслення радонових потенціалів територій і встановлення пріоритетності подальших досліджень.

Метою роботи $€$ обґрунтування методологічних аспектів дослідження територій щодо їхнього ступеня радононебезпечності.

Матеріали та методи досліджень. Вимірювання рівнів радону-222 проводились у повітрі житлових будинків відповідно до вимог «Норм радіаційної безпеки України (НРБУ-97)» [8] методом пасивної трекової радонометрії з використанням як детектора нітрат-целюлозної плівки типу LR-115 (Kodak). Радонові накопичувачі (радонометри) розміщувались у спальнях або дитячих кімнатах та експонувалися протягом 1-2 місяців. Після завершення експонування радонометри доставлялися до лабораторії, де вилучені детектори після процедури хімічного травлення обраховувалися на кількість треків ушкоджень методом іскрового підрахунку. Чутливість методу за 30добової експозиції становить 8-10 БK $\cdot \mathrm{M}^{-3}[9]$.

Для забезпечення системи гарантій якості вимірювань проводили калібрування детекторів (визначали ефективність реєстрації) шляхом експонування певної партії радонометрів у радоновій атмосфері з відомою об'ємною активністю (ОА) радону, яка має статус робочого еталону одиниці ОА радону-222. Для підтвердження коректності результатів вимірювань було проведено процедури звіряння з Шведською агенцією 3 протирадіаційного захисту (м. Стокгольм) та Національним інститутом радіологічних наук (Японія, м. Чіба).

Згідно з вимогами НРБУ-97 нормованою величиною $\epsilon$ значення середньорічної еквівалентної рівноважної об'ємної активності (ЕРОА) радону 222 у повітрі приміщень. Для будівель, які експлуатуються 3 постійним перебуванням людей, рівень обов'язкових дій не має перевищувати величину $100 \mathrm{БK} \cdot \mathrm{M}^{-3}[8]$.

EPOA радону-222 у повітрі приміщень визначали за формулою 1:

$A_{R n}=\frac{\bar{N}_{0}-\bar{N}_{\phi}}{\varepsilon_{R n} \cdot t} \cdot K_{s} \cdot F_{R n}$, БK $\cdot \mathrm{M}^{-3}$

де $\mathrm{N}_{0}$ - кількість треків експонованого детектора, трек $\mathrm{CM}^{-2}$ (визначається як середнє значення з трьох вимірювань); $N_{\phi}$ - власний фон певної партії НЦ плівки, трек $\cdot \mathrm{CM}^{-2}$

$\varepsilon_{R n}-$ ефективність реєстрації детектора з певної партії НЦ плівки у радоновій атмосфері (значення наведене у паспорті на трековий детектор), трек $\cdot \mathrm{CM}^{-2} \cdot \mathrm{БK}^{-1} \cdot \mathrm{M}^{-3} \cdot$ доба $^{-1}$; $t$ - час експонування, доба; $K_{\varepsilon}$ - поправочний коефіцієнт, що враховує відхилення від режиму травлення та підрахунку;

$F_{R n}$ - коефіцієнт рівноваги між радоном та його ДПР (рекомендоване МКРЗ значення - 0,4 [10]).

Середньорічне значення ЕРОА радону-222 розраховували як середнє значення результатів вимірювань, проведених у теплий та холодний періоди року. Для регіонів, в яких тривалість теплого (ТT) та холодного (ТХ) періодів року істотно відрізняються, середньорічне значення ЕРОА радону-222 у повітрі приміщень розраховували за формулою 2:

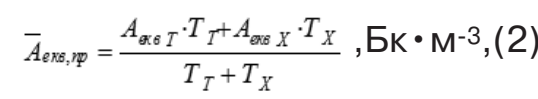

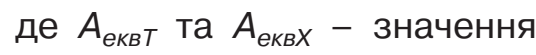
EPOA радону-222, отримані вимірюваннями у теплий та холодний періоди року, відповідно, Бк $\cdot \mathrm{M}^{-3}$.

Дослідження співвідношення ЕРОА радону-222 «зималіто» для різних регіонів країни наведено у роботі [11].

Значення річної ЕД опромінення за рахунок радону-222 у повітрі житлових приміщень розраховувалося за математичними моделями МКРЗ [10] за формулою 3:

$$
\bar{E}_{R n}=5,56 \cdot 10^{-6} \cdot 7000 \cdot 1,1 \cdot \bar{A}_{e \times \varepsilon, n p}=0,043 \cdot \bar{A}_{e x \varepsilon, n p}, \text { БК } \cdot \mathrm{M}^{-3},(3)
$$


ній дозі близько 10 мЗв [14]. Для аналізу результатів досліджень використовувалися стандартні методи статистичного аналізу даних.

Результати та обговорення. Вимірювання EPOA радону-222 проводились у повітрі житлових будинків різних регіонів України. Загалом здійснено понад 30 тисяч вимірювань.

Рівні радону у повітрі будинків. Аналізом результатів досліджень встановлено, що частотний розподіл активностей радону у повітрі будинків має логнормальний характер (рисунок).

Середнє геометричне значення EPOA радону-222 для одноповерхових будинків сільського типу склало 52 Бк - $\mathrm{M}^{-3}$ (у термінах ОА 130 Бк $\left.\mathrm{M}^{-3}\right)$, для квартир, які розташовані на першому поверсі багатоповерхових будинків - 40 (100) Бк・ $\mathrm{M}^{-3}$, вище першого поверху - 23 (58) Бк $\mathrm{M}^{-3}$. Стандартне відхилення ЕРОА радону-222 для першого типу будинків становить 62 (155) Бк $\mathrm{M}^{-3}$, другого типу - 48 (120) Бк $\cdot \mathrm{M}^{-3}$, третього типу - $28(70)$ Бк $\cdot \mathrm{M}^{-3}$. Встановлено, що основні параметри розподілу прак-

Рисунок 1

Частотний розподіл ЕРОА радону-222 у повітрі будинків України
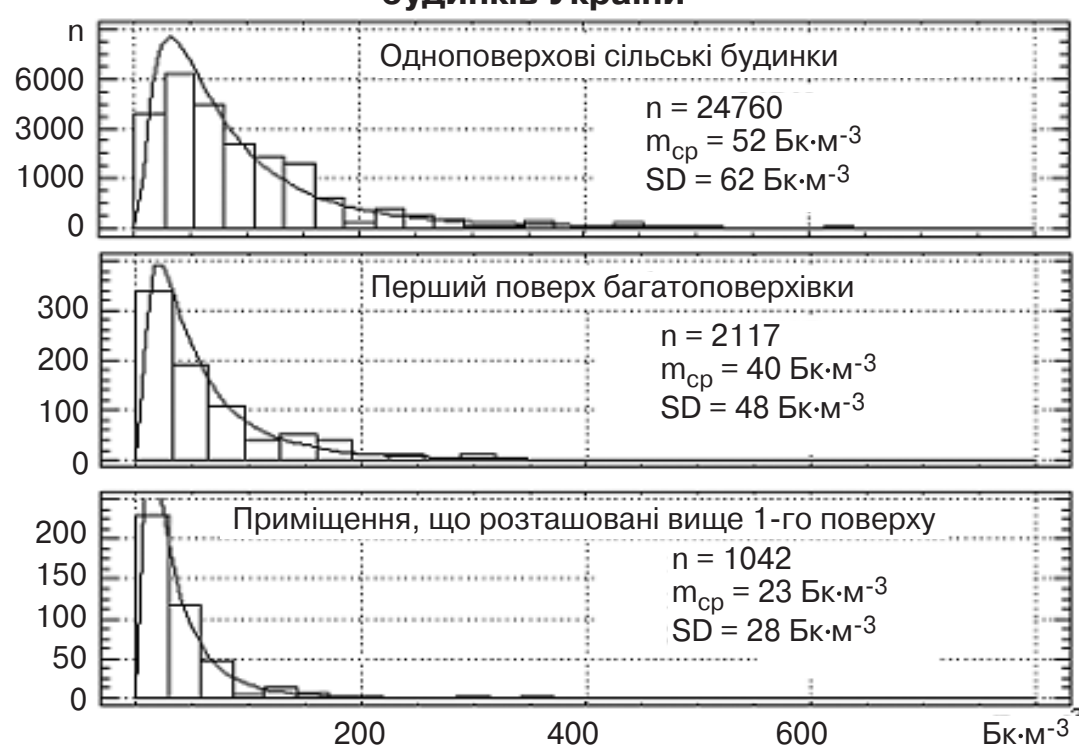

Примітка: $n$ - кількість будинків;

$m_{c p}$ - середнє геометричне значення ЕРОА радону-222;

SD - стандартне відхилення ЕРОА радону-222. тично не змінилися зі збільшенням кількості вимірювань.

Аналізом результатів досліджень встановлено, що у середньому по країні рівень нормативу для радону-222 100 (250) Бк м $^{-3}$ перевищується у $19 \%$ випадків, 200 (500) Бк $\cdot \mathrm{M}^{-3}$ - у середньому перевищується у 5,7\% випадків, ймовірність наявності будинків з EPOA радону-222 понад 400 (1000) Бк $\cdot \mathrm{M}^{-3}$ становила 0,01\%.

У таблиці 1 наведено основні статистичні параметри щодо ЕРОА радону-222. Для порівняння наведено відсоток будинків, де було зафіксовано перевищення EPOA радону у $50(125)$ Бк $\left.\cdot \mathrm{M}^{-3}\right) 100$ (250) БК $\cdot \mathrm{M}^{-3}$ та 200 (500) БK $\cdot \mathrm{M}^{-3}$

Методологічні підходи до оптимізації моніторингу радону. За результатами досліджень було розраховано середньорічні ЕД опромінення населення від радону. Встановлено, що найбільші дози отримує сільське населення країни. Якщо проаналізувати частотний розподіл ЕД опромінення, обумовлених цим джерелом, то на першому етапі до когорти осіб з підвищеними дозами можна віднести 0,01\% сільського населення, тобто близько 400 тисяч осіб, які отримують середньорічні ЕД понад 20 мЗв • рік-1.

В окремих випадках значні ЕД опромінення може отримувати міське населення, наприклад у регіонах, де розвинута видобувна промисловість - містах Кривий Ріг і Кропивницький. Такі міста розташовуються поряд 3 шахтами, а інколи і над старими виробками шахт.

Окрім того, вони мають специфічну житлову забудову, яка формувалася у 60-70ті роки минулого століття, переважно так звані «хрущовки».

Дослідженнями встановлено, що рівні радону-222 у таких будинках не лише на 
FEATURES OF PLANNING OF THE STUDIES OF INDOOR AIR LEVELS WITHIN THE ACTION PLAN IMPLEMENTATION

1Pavlenko T.O., 1Aksonov M.V., 1 Fryziuk M.A., 2 Operchuk A.P., 1 Fedorenko O.V.

1SI «O.M. Marzieiev Institute for Public Health, NAMSU», Kyiv, Ukraine

${ }^{2}$ SI «Public Health Centre of Ukraine, Ministry of Public Health of Ukraine», Kyiv, Ukraine

Objective: Our aim was to substantiate the methodological aspects of the study of the radon hazard of the territories.

Materials and methods: The measurements of the radon-222 levels were carried out with the help of the passive track radonometry method in the heating season. Cellulose nitrate film of LR-115 type was used as a detector. The time of the exposure of radon accumulators made up 1-2 months. After the chemical etching procedure, the detectors were counted for the number of damage tracks by the method of spark counting. To establish the registration efficiency of the track detectors (calibration), they were exposed in the radon atmosphere with a known radon activity. The radon atmosphere, patented by the Institute of Public Health, is a calibration source accredited by the National Body of Standardization and Accreditation of Ukraine.

Results: Indoor radon-222 measurements were performed in more than 30 thousands buildings. The indoor radon-222 EEVA geometric mean for rural houses was found to be $52 \mathrm{~Bq} \cdot \mathrm{m}^{-3}$ (for gas radon, this value is $130 \mathrm{~Bq} \cdot \mathrm{m}^{-3}$ ), for apartments located on the ground floor of multi-storied buildings 40 (100) $\mathrm{Bq} \cdot \mathrm{m}^{-3}$, above the ground floor 23 (58) $\mathrm{Bq} \cdot \mathrm{m}^{-3}$ with a standard deviation of 62 (155) Bq $\cdot \mathrm{m}^{-3}, 48(120) \mathrm{Bq} \cdot \mathrm{m}^{-3}$ and $28(70) \mathrm{Bq} \cdot \mathrm{m}^{-3}$, correspondently.

The national average level of the standard for radon-222 of 100 (250) $\mathrm{Bq} \cdot \mathrm{m}^{-3}$ was found to be exceeded in $19 \%$ of cases, the level of 200 (500) $\mathrm{Bq} \cdot \mathrm{m}^{-3}-$ in $5.7 \%$ of cases.

Effective radiation doses for the population of the country have been determined. Non-radiation factors, affecting the effectiveness of studies, have been analyzed.

The algorithm for the assessment of the radon risk degree for the territory has been developed. It includes the analysis of the structure of housing resources, determination of the most typical engin eering-and-planning solutions for buildings, integral method of radon measurement, identification of the critical types of buildings based on the measurements of radon levels, calculation of radiation risks from radon for the population.

The basic requirements for the primary radon monitoring in the context of the action plan implementation have been identified.

Keywords: indoor radon, effective dose, radiation risks, algorithm for actions. перших поверхах, але й у квартирах, розташованих вище першого поверху, можуть

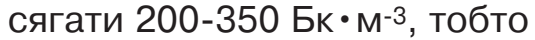
ЕД їхніх мешканців становлять 8-13 мЗв • рік-1 $[15,16]$.

Території таких населених пунктів мають бути віднесеними до категорії радононебезпечних, тому будівлі у них необхідно досліджувати першочергово. У такому випадку до планів первинного обстеження необхідно вносити вимірювання не лише на перших поверхах багатоповерхових будинків, але й на поверхах, розташованих вище.

Таким чином, основною задачею аналізу попередніх досліджень $€$ визначення критичних груп населення, які потенційно можуть отримувати дози опромінення, неприйнятні щодо рівнів

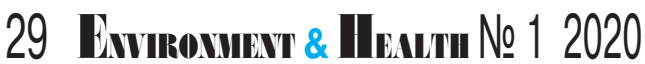

радіаційно-гігієнічних регламентів. Реалізація програм ремедіації щодо радону-222 у будинках для цієї групи дасть максимальну ефективність як за дозовим критерієм, так і за соціальноекономічними наслідками втручання.

Необхідно зауважити, що оцінки колективних доз опромінення не можна використовувати як критерій для процедур оптимізації. Ілюстрацією до цього твердження $€$ аналіз доз опромінення населення на регіональному рівні. На рисунку 2 представлено результати аналізу ЕД опромінення від радону222 у повітрі житлових будинків Київської області на рівні окремих районів, а на рисунку 3 - відповідні колективні дози опромінення населення цього регіону. 3 рисунка 2 видно, що максимальні ЕД опромінення отримує населення південних районів області: Рокитнянського, Богуславського, Таращанського, Володарського, Тетіївського. Але якщо Рокитнянський та Богуславський райони і за ефективними, і за колективними дозами опромінення мешканців потрапляють до категорії найбільш небезпечних, то за колективною дозою до цієї категорії можна також віднести і Броварський, Вишгородський та Бориспільський райони, населення яких отримує ЕД у середньому вдвічі менші дози порівняно 3 населенням південних районів (рис. 2 і 3).

Таким чином, використання колективних доз як параметра під час оптимізації може 
Ще одна специфічна ознака, на яку варто звернути увагу - це тип будинків. Аналіз результатів вимірювань встановив наявність для кожного регіону типових радононебезпечних будинків. Так, для центральних областей країни - це саман- ні будинки, для південних будинки з черепашника тощо. Для прикладу у таблиці 2 наведено дані щодо перевищення нормативу у типових будинках окремих районів Київської області. Якщо загалом по Київській області для одноповерхових сіль-

Таблиця 1

Основні статистичні дані щодо вмісту радону-222 у повітрі одноповерхових будинків сільського типу

значно вплинути на програми моніторингу радону, передусім на його вартість. Це пов'язане з тим, що варіабельність рівнів радону на рівні населених пунктів може становити до двох порядків. Наприклад, якщо визначити кількість будинків, в яких необхідно провести вимірювання, а потім реалізувати протирадонові заходи, то для Броварського та Бориспільського районів їхня кількість становитиме близько 200 будинків, для Рокитнянського району - вже майже 3200, а для Богуславського - 5200 будинків. Тобто ефективніше на першому етапі концентрувати усі ресурси на тих регіонах, де будуть вищими середньозважені ЕД опромінення, а не колективні дози, за якими розраховуються радіаційні ризики.

\begin{tabular}{|c|c|c|c|c|c|}
\hline \multirow{2}{*}{ Область } & \multirow{2}{*}{$\begin{array}{c}\text { Середнє } \\
\text { геометричне } \\
\text { ЕРОА/ОА, } \\
\text { Бк } \mathbf{M}^{-3}\end{array}$} & \multirow{2}{*}{$\begin{array}{c}\text { Стандартне } \\
\text { відхилення } \\
\text { ЕРОА/ОА, } \\
\text { Бк• } \text { м }^{-3}\end{array}$} & \multicolumn{3}{|c|}{$\begin{array}{l}\text { Відсоток переви- } \\
\text { щень ЕРОА, Бк• } \text { м-3 }^{-1}\end{array}$} \\
\hline & & & 50 & 100 & 200 \\
\hline Вінницька & $41 / 103$ & $71 / 178$ & 42,9 & 22,6 & 5,8 \\
\hline Волинська & $13 / 33$ & $11 / 28$ & 0,9 & 0,2 & 0,0 \\
\hline Дніпропетровська & 75 / 188 & $97 / 243$ & 69,8 & 41,9 & 13,8 \\
\hline Житомирська & $42 / 105$ & $66 / 165$ & 45,3 & 18,3 & 3,8 \\
\hline Запорізька & $46 / 115$ & $71 / 178$ & 49,6 & 21,4 & 5,3 \\
\hline Кіровоградська & $29 / 73$ & 82 / 205 & 33,3 & 14,8 & 3,7 \\
\hline Київська & $30 / 75 /$ & $63 / 158$ & 30,4 & 13,4 & 3,4 \\
\hline Миколаївська & $36 / 90$ & 98 / 245 & 35,9 & 13,6 & 9,7 \\
\hline Одеська & $32 / 80$ & $68 / 170$ & 26,9 & 11,8 & 1,7 \\
\hline Полтавська & $24 / 60$ & $43 / 108$ & 21,4 & 9,6 & 1,3 \\
\hline Рівненська & $14 / 35$ & 26 / 65 & 8,6 & 2,8 & 0,3 \\
\hline Сумська & $19 / 48$ & $28 / 70$ & 10,9 & 3,4 & 0,7 \\
\hline Тернопільська & $85 / 213$ & $107 / 268$ & 71,3 & 42,6 & 15,5 \\
\hline Херсонська & $106 / 265$ & $102 / 255$ & 88,3 & 53,3 & 16,7 \\
\hline Черкаська & $64 / 160$ & $84 / 210$ & 64,9 & 36,9 & 8,9 \\
\hline Чернігівська & $21 / 53$ & $29 / 73$ & 8,1 & 1,2 & 0,2 \\
\hline
\end{tabular}

Рисунок 2

Середньозважені дози опромінення населення Київської області

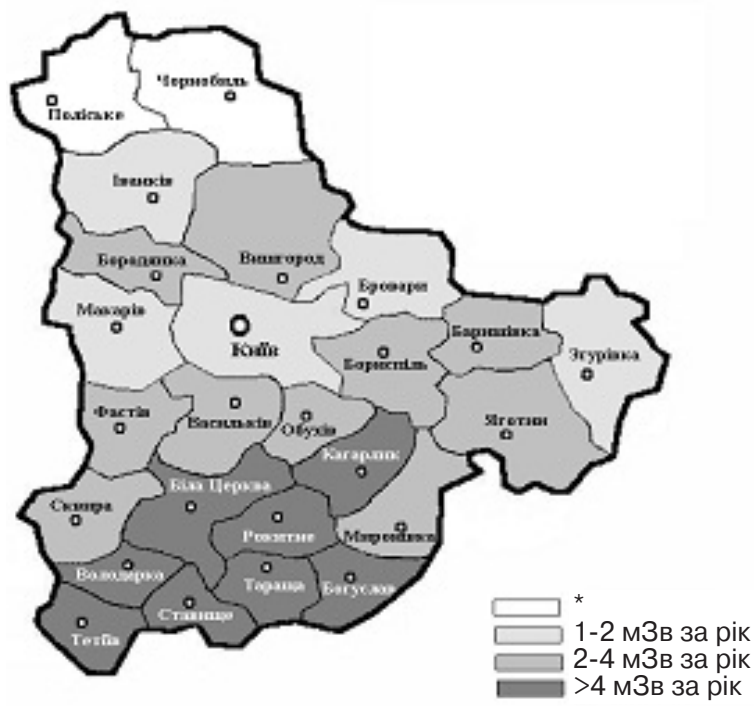

Колективні дози опромінення Рисунок 3 населення Київської області

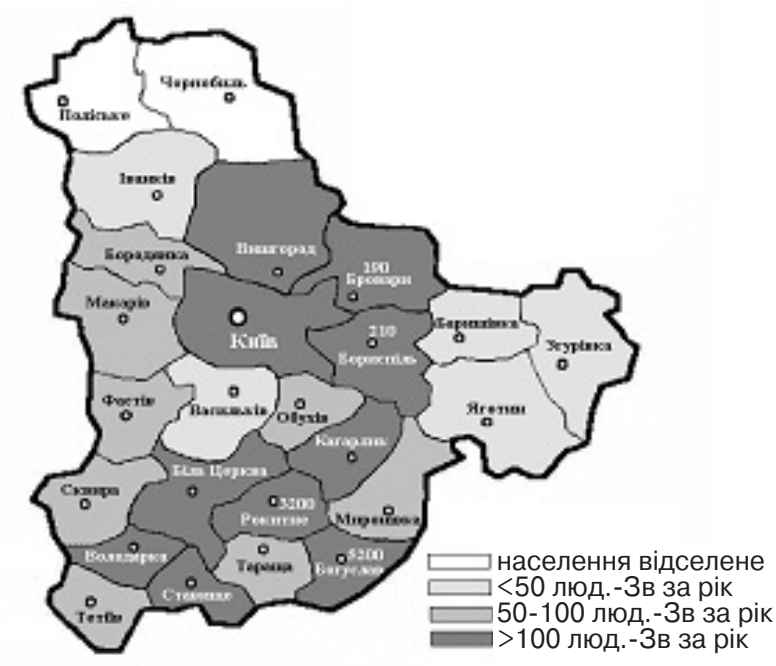

Примітка: * - офіційно населення було відселене. 


\section{ОСОБЕННОСТИ ПЛАНИРОВАНИЯ \\ ИССЛЕДОВАНИЙ УРОВНЕЙ РАДОНА \\ В ВОЗДУХЕ ЗДАНИЙ В РАМКАХ \\ РЕАЛИЗАЦИИ ПЛАНА ДЕЙСТВИЙ \\ 1 Павленко Т.А., 1 Аксенов Н.В., 1Фризюк М.А., 2Оперчук А.П., 1 Федоренко Е.В. \\ 1 ГУ «Институт общественного здоровья им. А.Н. Марзеева НАМН Украины», г. Киев, Украина \\ 2ГУ «Центр общественного здоровья Министерства здравоохранения Украины», г. Киев, Украина}

Цель работы. Обоснование методологических аспектов исследования радоноопасности территорий.

Материалы и методы исследования. Измерения уровней радона-222 проводились в отопительный сезон методом пассивной трековой радонометрии с использованием в качестве детектора нитрат-целлюлозной пленки типа LR-115. Время экспонирования радоновых накопителей составляло 1-2 месяца. Детекторы после процедуры химического травления обсчитывались по количеству треков повреждений методом искрового счета.

Для определения эффективности регистрации трековых детекторов (калибровки) их экспонировали в радоновой атмосфере $c$ известной активностью радона. Радоновая атмосфера, запатентованная в Институте общественного здоровья НАМН Украины, является эталоном, аккредитованным Национальным органом стандартизации и аккредитации Украины.
Результаты. Выполнены измерения радона-222 в воздухе более 30 тысяч жилых зданий. Установлено, что среднее геометрическое значение ЭРОА радона222 для одноэтажных домов сельского типа составило 52 Бк $\cdot M^{-3}$ (в терминах OA 130 Бк・M-3), для квартир, расположенных на первом этаже многоэтажных домов 40 (100) Бк・M-3, выше первого этажа 23 (58) Бк $M^{-3}$, при стандартном отклонении - 62(155) Бк・M-3, 48(120) БК $M^{-3}$ и 28 (70) Бк $\mathrm{M}^{-3}$ соответственно.

Установлено, что в среднем по стране уровень норматива для радона-222 в 100 (250) Бк $\cdot M^{-3}$ превышается в $19 \%$ случаев, уро-

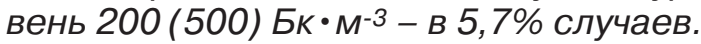
Определены эффективные дозы облучения населения страны. Проанализированы нерадиационные факторы, влияющие на эффективность исследований.

Разработан алгоритм оценки степени радоноопасности территории, который включает анализ структуры жилищного фонда, определение наиболее типичных инженерно-планировочных решений зданий, измерения радона интегральным методом, выявление критичных типов зданий по результатам измерений уровней радона, расчета радиационных рисков населения от радона.

Определены основные требования к первичному мониторингу радона в контексте реализации радонового плана действий.

\section{Ключевые слова: радон в домах, эффективная доза, радиационные риски, алгоритм действий.}

ських будинків перевищення радіаційно-гігієнічного регламенту зафіксовано у 13\% випадків, то для цегляних будинків перевищення становить 15\%, для дерев'яних - 12\%, для саманних - 43\%. Але на рівні окремих районів, залежно від превалюючої структури житлового фонду, ці співвідношення варіюють у дуже широких межах.

Так, для північних районів Київської області критичним типом є цегляні будинки. Для Переяслав-Хмельницького району лише в 1\% будинків такого типу зафіксоване підвищені рівні радону-222. Для Рокитнянського району ця величина склала 45\%, для Таращанського - 31\%. Сaманні будинки на півночі не зустрічаються, а от на півдні області (це критичний тип будівель) перевищення сягає $75 \%$.

\section{Відповідність будинків різних типів вимогам} радіаційно-гігієнічних регламентів

\begin{tabular}{|c|c|c|c|c|c|c|}
\hline \multirow[b]{2}{*}{ Район } & \multicolumn{2}{|c|}{ Дерев'яні } & \multicolumn{2}{|c|}{ Цегляні } & \multicolumn{2}{|c|}{ Саманні } \\
\hline & $\begin{array}{c}\text { Кіль- } \\
\text { кість } \\
\text { будин- } \\
\text { ків }\end{array}$ & $\begin{array}{c}\text { \% пере- } \\
\text { вищень } \\
250 \\
\text { Бк·м-3 }\end{array}$ & $\begin{array}{c}\text { Кіль- } \\
\text { кість } \\
\text { будин- } \\
\text { ків }\end{array}$ & $\begin{array}{c}\% \text { пере- } \\
\text { вищень } \\
250 \\
\text { Бк } \text { M }^{-3}\end{array}$ & $\begin{array}{c}\text { Кіль- } \\
\text { кість } \\
\text { будин- } \\
\text { ків }\end{array}$ & $\begin{array}{c}\text { \% пере- } \\
\text { вищень } \\
250 \\
\text { Бк· } \text { м }^{-3}\end{array}$ \\
\hline Богуславський & 181 & 45 & 336 & 38 & 32 & 53 \\
\hline Бородянський & 362 & 7 & 213 & 10 & 0 & 0 \\
\hline Обухівський & 58 & 12 & 105 & 20 & 4 & 75 \\
\hline $\begin{array}{l}\text { Переяслав- } \\
\text { Хмельницький }\end{array}$ & 134 & 3 & 317 & 1 & 0 & 0 \\
\hline Рокитнянський & 184 & 64 & 489 & 45 & 28 & 75 \\
\hline Таращанський & 83 & 22 & 323 & 31 & 7 & 29 \\
\hline Київська обл. & 2916 & 12 & 4732 & 15 & 169 & 43 \\
\hline
\end{tabular}

Для кожного регіону країни традиційні інженернопланувальні рішення будинків будуть істотно відрізня-

Таблиця 2

\section{.}




\section{Висновки}

1. Встановлено, що для дослідження територій щодо їхного ступеня радононебезпечності методологія моніторингу радону має передбачати аналіз структури житлового фонду та визначення найбільш типових інженерно-планувальних рішень будівель для обраного регіону, визначення найбільш радононебезпечних типів будівель за результатами досліджень рівнів радону, а також розрахунок ефективних доз та радіаційних ризиків населення, яке мешкає на цих територіях.

2. Вимірювання рівнів радону належить проводити інтегральними методами за єдиними протоколами. Організація досліджень має обов'язково забезпечити систему гарантій якості вимірювань - процедури звіряння між лабораторіями, які беруть участь у проведенні вимірювань.

3. За результатами попередніх досліджень встановлено, що середнє геометричне значення ЕРОА радону-222 для одноповерхових будинків сільського типу становило 52 Бк $\cdot \mathrm{M}^{-3}$ (у термінах $\left.\mathrm{OA}-130 \mathrm{5K} \cdot \mathrm{M}^{-3}\right)$, для квартир, які розташовані на першому поверсі багатоповерхових будинків - 40 (100) Бк $\cdot \mathrm{M}^{-3}$, вище першого поверху - 23 (58) БK $\mathrm{M}^{-3}$. Стандартне відхилення ЕРОА радону 222 для першого типу будинків становить 62 (155) Бк $\cdot \mathrm{M}^{-3}$, другого типу - 48 (120) Бк $\cdot \mathrm{M}^{-3}$, третього типу $28(70) 5 \mathrm{~K} \cdot \mathrm{M}^{-3}$.

4. У середньому по країні рівень нормативу для радону-222 100 (250) Бк $\cdot \mathrm{M}^{-3}$ перевищується у $19 \%$ випадків, $200(500)$ Бк $\cdot \mathrm{M}^{-3}$ - у 5,7\% випадків, імовірність наявності будинків з ЕРОА радону222 понад $400(1000)$ Бк $\cdot \mathrm{M}^{-3}$ становить $0,01 \%$.

5. Встановлено, що найбільші дози від радону-222 отримує сільське населення країни. Близько 400 тисяч осіб $(0,01 \%$ сільського населення) отримують дози понад 20 мЗв рік $^{-1}$.

\section{ЛІТЕРАТУРА}

1. ICRP Publication 101b. The Optimisation of Radiological Protection: Broadening the Process. Annals of the ICRP. 2006 Vol. 36 (3). P. 69-104.

2. Barnet I., Pacherova P., Smyckova L. Aktualizovane mapy radonoveho indexu Ceske republiky v meritku 1 : 50 000. Zpravy o geologickych vyzkumech v roce 2012. 2012. 45. P. 156-161.

3. EPA. Radon map of England. URL :

https://www.ukradon.org/infor mation/ukmaps (Mode of access : 15.05.2019).

4. EPA. Radon map of Switzerland. URL : https://www.bag.admin.ch/ba g/en/home/gesundleben/umwelt-und-gesundheit/strahlung-radioaktivitaetschall/radon/radongebietech.html (Mode of access : 15.05.2019).

5. Gruber V., Bossew P. De Cort M., Tollefsen T. The European map of the geogenic radon potential. J. Radiol. Prot. 2013. Vol. 33 (1). P. 51-60. doi: 10.1088/0952-4746/33/1/51. 6. Radon Risk Mapping: JRC leading efforts to harmonise European map of radon levels. URL : $h$ ttps:// ec.europa.eu/jrc/en/news/ra don-risk-mapping-jrc-leading-efforts-harmonise-european-map-radon-levels-7372 (Mode of access : 15.05.2019).

7. Bossew P., Tollefsen T., Cinelli G., Gruber V.,

De Cort M. Status of the European Atlas of Natural Radiation. Radiat. Prot. Dosimetry. 2015. Vol. 167 (13). P. 29-36.

doi:10.1093/rpd/ncv216

8. Норми радіаційної безпеки України (НРБУ-97) : Державні гігієнічні нормативи. ДГН 6.6.1.-6.5.001-98. К., 1998. 135 C.

9. Вимірювання концентрації радону-222 у повітрі радоном населення у рамках Державного плану дій. 
будинків методом пасивної трекової радонометрії з використанням приладу «Track 2010Z»:

методичні вказівки з методів контролю (МВК 6.6.2.-0632000) / МОЗ України.

K., 2000. 21 c.

10. ICRP Publication 65.

Protection against Radon-222 at Home and at Work. Annals of the ICRP. 1994. Vol. 23 (2). P. 1-78.

11. Pavlenko T.A., Los I.P., Aksenov N.V. Exposure Doses due to Indoor Rn-222 in Ukraine and Basic Directions for Their Decrease. Radiat. Measur. 1997. Vol. 28 (1-6). P. 733-738.

12. ICRP Publication 103. Recommendations of the International Commission on Radiological Protection. Annals of the ICRP. 2007. 37 (2-4). P. 1-332.

13. ICRP Publication 126. Radiological Protection against Radon Exposure. Annals of the ICRP. 2014. Vol. 43 (3).

P. 1-73.

14. ICRP Publication 137. Occupational Intakes of Radionuclides: Part 3. Annals of the ICRP. 2017. Vol. 46 (3/4). P. 1-486. doi: $10.1177 / 0146645317734963$.

15. Іщенко Л.О. Радіаційногігієнічне обстеження житлових приміщень Криворізького залізорудного регіону. Гігієна населених місць : зб. наук. пр. К., 2008. Вип. 52. C. 256-260.

16. Іщенко Л.О. Рівні дозових навантажень від радону у житлових приміщеннях м. Кривого Рогу. Вестник гигиены и эпидемиологии. 2008. T. 12. № 1.

C. 119-122.

\section{REFERENCES}

1. ICRP Publication 101b. The Optimisation of Radiological Protection: Broadening the Process. Annals of the ICRP. 2006 ; 36 (3) : 69-104.

2. Barnet I., Pacherova P., Smyckova L. Aktualizovane mapy radonoveho indexu
Ceske republiky v meritku 1 : 50 000. Zpravy o geologickych vyzkumech v roce 2012. 2012 ; 45 : 156-161.

3. EPA. Radon Map of England. URL :

https://www.ukradon.org/info rmation/ukmaps

(Mode of access :

15.05.2019).

4. EPA. Radon Map of

Switzerland. URL :

https://www.bag.admin.ch/ba g/en/home/gesund-

leben/umwelt-und-gesundheit/strahlung-radioaktivitaetschall/radon/radongebietech.html (Mode of access : 15.05.2019).

5. Gruber V., Bossew P., De Cort M. and Tollefsen T. J. Radiol. Prot. 2013 ; 33 (1) : 51-60. doi: 10.1088/09524746/33/1/51.

6. Radon Risk Mapping: JRC Leading Efforts to Harmonise European Map of Radon Levels. URL :

https://ec. europa.eu/jrc/en/n ews/radon-risk-mapping-jrcleading-efforts-harmoniseeuropean-map-radon-levels7372 (Mode of access : 15.05.2019).

7. Bossew P., Tollefsen T., Cinelli G., Gruber V. and De Cort M. Radiat. Prot. Dosimetry. 2015; 167 (1-3) : 29-36.

doi:10.1093/rpd/ncv216

8. Normy radiatsiinoi bezpeky Ukrainy (NRBU-97) : Derzhavni hihienichni normatyvy DHNK 6.6.1.-6.5.00198. [Norms of Radiation

Safety of Ukraine (NRSU-97) : State Hygienic Standards.

SHS 6.6.1.-6.5.001-98].

Kyiv; 1998 : 135 p.

(in Ukrainian).

9. Ministry of Public Health of Ukraine. Vymiriuvannia kontsentratsii radonu-222 u povitri budynkiv metodom pasyvnoi trekovoi radonometrii z vykorystanniam pryladu «Track 2010Z» : metodychni vkazivky z metodiv kontroliu (MBK 6.6.2.-063-2000).

[Measurement of the Indoor Radon-222 Concentration by the Method of Passive
Track Radonometry with «Track 2010Z»

Device : Guidance on Control Methods (GCM 6.6.2.-0632000)]. Kyiv ; $2000: 21$ p. (in Ukrainian).

10. ICRP Publication 65. Protection against Radon-222 at Home and at Work.

Annals of the ICRP. 1994; 23

(2) : 1-78.

11. Pavlenko T.A., Los I.P. and Aksenov N.V. Radiat. Measur. 1997 ; 28 (1-6) : 733-738.

12. ICRP Publication 103. Recommendations of the International Commission on Radiological Protection. Annals of the ICRP. 2007 ; 37 (2-4) : 1-332.

13. ICRP Publication 126. Radiological Protection against Radon Exposure. Annals of the ICRP. $2014 ; 43$ (3) : 1-73.

14. ICRP Publication 137. Occupational Intakes of Radionuclides: Part 3. Annals of the ICRP. $2017 ; 46$ (3/4) : 1-486. doi:

$10.1177 / 0146645317734963$.

15. Ishchenko L.O.

Radiatsiino-hihiienichne obstezhennia zhytlovykh prymishchen Kryvorizkoho zalizorudnoho rehionu

[Radiation-Hygienic

Examination of the Residential Premises in Kryvyi Rih Iron Ore Region]. Hihiiena naselenykh mists : zb. nauk. prats. Kyiv ; 2008 ; 52 : 256-260 (in Ukrainian).

16. Ishchenko L.O. Vestnik gigieny l epidemiologii. 2008. T. 12. № 1. C. 119-122 (in Ukrainian).

Надійшло до редакції 15.06.2019 